\title{
Exploration of Culinary Tourism in Indonesia: What Do the International Visitors Expect?
}

\author{
Serli Wijaya ${ }^{1,}$ Alison Morrison ${ }^{2}$, Thu-Huong Nguyen ${ }^{3}$, Brian King ${ }^{4}$ \\ ${ }^{1}$ Faculty of Business \& Economics, Petra Christian University Surabaya, Indonesia \\ serliw@petra.ac.id \\ ${ }^{2-3}$ College of Business, Victoria University, Melbourne, Australia \\ ${ }^{4}$ School of Hotel \& Tourism Management, The Hong Kong Polytechnic University, Hong Kong, China
}

\begin{abstract}
More visitors are nowadays travelling to destinations in search of culinary experiences. Food functions not merely as physiological sustenance but also as a destination experience enhancer, providing opportunities to learn about destination culture through direct encounters with local cuisines. This study aimed to identify the international visitor preconceptions of local Indonesian food and the factors influencing their expectations prior to dining with the local food in the country. A questionnaire-based survey involving 349 international visitors was completed. The results revealed seven new emerging factors expected as relating to: staff quality, sensory attributes, food uniqueness, local servicescapes, food authenticity, food familiarity, and food variety. Further, there were significant differences in the level of dining expectations amongst participants who travelled to Indonesia for the first time compared to those who had visited the country before.
\end{abstract}

Keywords - culinary tourism, dining expectation, international visitor, local Indonesian food

\section{INTRODUCTION}

Food is an essential component of tourism along with transportation, accommodation, and attractions. When travelling, visitors engage in some forms of dining [1], ranging from eating food which is familiar from home to seeking novel and different local dishes [2]. Seeking experiences with the food of a destination has gained increasing attention amongst the visitors. That is, food functions is no longer as physiological need fulfillment only but also as a destination experience enhancer, offering opportunities to learn about destination culture through direct encounters with local cuisines. Experiencing local food can provide a gateway to new cultures, leading visitors to learn about the culture of societies other than their own and to meet locals with whom they [3, 4]. Since eating is an integral part of travelling, it is commonplace for visitors to expect pleasurable culinary experiences [5]. The term culinary tourism can be intepreted as a tourism trip, during which the consumption or experience of local food and beverages is expressed in various foodrelated activities, regardless of whether experiencing local food is or is not a primary purpose for travel [6-7]. Recent attempts to utilise culinary tourism as a destination attraction have been evident in Asia, particularly in leading tourism destinations such as Hong Kong [8-10], Singapore [11, 12], and Taiwan $[13,14]$. It is apparent that these countries have moved towards the tendency of expanding its culinary tourism to stimulate international visitation [15].

Tourism is considered as one of the fastest growing sectors that support Indonesian economy. In 2014, the country welcomed about 9,4 million international visitors, indicating a $7.19 \%$ growth from 2013 [16]. Data reported by the Ministry of Tourism and Creative Economy of the Republic of Indonesia showed that in 2010, visitors spent about $18-20 \%$ of their total tourism consumption on food and beverages, recorded as the second highest expense [17]. As a country with rich natural and cultural resources, Indonesia can potentially benefit from a focus on culinary tourism to strengthen its international visitor appeal. There are more than 485 ethnic groups in Indonesia, each having its own local food characteristics. This has endowed the national cuisine with variety and taste [18]. There are thousands of local foods that can offer a strong focal point for portraying Indonesia as a tourism destination. Indeed, it has led to uniqueness and a diversity of food-related activities that international visitors could experience when travelling there [19].

However, it still remains a challenge to establish Indonesia's position as a world-class food tourism destination. Having very diverse traditional dishes may pose a difficulty to select which particular food to promote to the international market [20]. In fact, since the past few years, there has been a growing support from the government to promote Indonesian culinary diversity and richness to the international market level. Culinary tourism is considered to be one of the seven types of special interest tourism prioritised for development. In December 2012, the Ministry of Tourism and Creative Economy officially launched 30 signature traditional dishes of Indonesia aiming to improve the awareness level of the Indonesian culinary diversity in the international market [21]. Support for promoting Indonesian cuisine is also given by the national carrier, Garuda Indonesia, through the launch of the Garuda Indonesia Experience concept which is designed to provide pre-, on, and, after flight services characterised by Indonesian hospitality. This includes the provision of signature traditional dishes for on-board meals such as nasi kuning (Indonesian yellow rice), and nasi rendang (beef 
stewed with coconut paste) [22]. Recetly in 2015, the Ministry of Tourism and Creative Economy has determined four cities of Indonesia, namely: Bandung, Yogyakarta, Solo, Semarang and Bali, as Indonesian culinary destinations [23].

The existing literature has indicated that the majority of culinary tourism studies examining visitor behaviour were taken in more touristically developed destinations [2, 24]. In an Asian context, to the author's knowledge, no empirical study has investigated food experiences involving international visitors in regard to their consumption of local Indonesian food. Conducting an empirical investigation in Indonesia is thus of particular interest, allowing for an examination of how food culture differences can shape and affect the overall dining experiences with local food encountered by international visitors in the country. Considering these shortcomings, this exploratory study aimed to discover these there following questions:

1. What are the international visitor preconceptions of local Indonesian food?

2. What the underlying factors influencing international visitor expectations prior to engaging with local food dining in Indonesia?

3. Are the dining expectation level varied significantly between the international visitors who first time travelling to Indonesia and those who had ever visited the country before?

\section{RESEARCH METHOD}

A questionnaire-based survey involving a total of 349 international visitors who travelled to Indonesia was completed. They were asked: 1) basic profiles relating to demographics and travel characteristics; 2) preconceptions or knowledge about local Indonesian food (open-ended questions); 3) attributes that were important to be expected prior to actual dining experiences with local Indonesian food (using a five-point Likert scale). The participants were approached mainly at Juanda International Airport Surabaya, East Java at the arrival terminal, and at the four and five star hotel lobbies in Surabaya and Malang, East Java. Exploratory Factor Analysis (EFA) was applied to identify the underlying external factors which influenced visitor dining expectations. In addition, MANOVA analysis was undertaken to find out whether there were any significant differences in dining expectation level between the participants who travelled to Indonesia for the first time and those who had ever visited the country before.

\section{FINDINGS AND DISCUSSION}

\section{A. Participant Profiles}

The participants were dominated by males, aged 30 years old above (51.3\%), from European countries (56.7\%), who were working $(57.8 \%)$, and had attained their highest education level minimum at diploma or bachelor degree level (77.6\%). With regard to purpose of travel to Indonesia, the majority of participants $(41 \%)$ visited Indonesia for holidays; there was a fairly equal composition of those who travelled for education/cultural exchange (28.4\%) and for business/MICE (24.4\%); identified as first time visiting Indonesia (63.3\%); spent more than one week of travel $(63.9 \%)$; and travelled with a group of people or tourists $(39.3 \%)$.

\section{B. Preconceptions of Local Indonesian Food}

Although the majority of participants stated that they visited Indonesia for the first time, most of them (78.8\%) had heard about local Indonesian food before their actual visit. It is more likely that respondents received information pertaining to local Indonesian food verbally by word-of-mouth (WOM) from their friends, family or relatives, rather than from written sources like magazines or newspaper articles about Indonesian cuisines. Participant preconceptions were examined based on their knowledge about the most salient characteristics of local Indonesian food. The finding is illustrated in the form of tag clouds at Figure 1. The larger font size of words in the tag cloud indicates the more frequent the characteristics being mentioned by the participants.

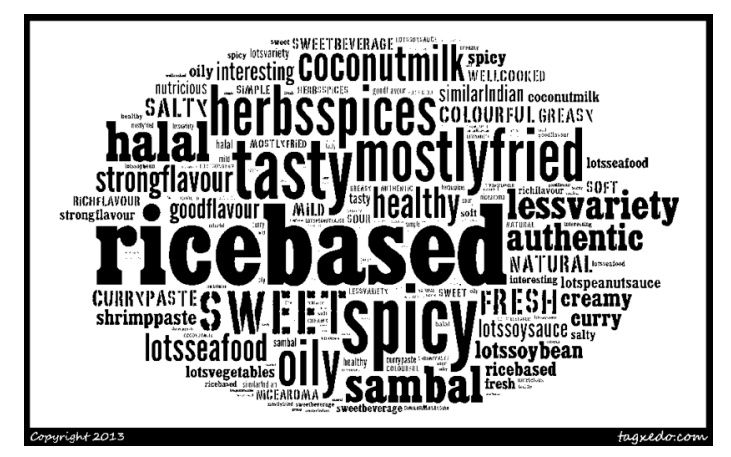

Fig. 1 The most frequently occurring words that appear in the combined responses relating to characteristics of local Indonesian food

As seen in Figure 1, rice-based, spicy, tasty, sweet, mostly fried (similar to oily), herbs spices, sambal, and halal, were words most frequently associated with local Indonesian cuisine. The first four words of rice-based, spicy, tasty, sweet are related to the food taste while herbs spices and sambal refer to the ingredients used in the dishes. Moreover, mostly fried (oily) was the characteristic concerned with the way of cooking the food. Interestingly, participants' identification of major characteristics also revealed that local Indonesian food was preconceived as halal. Given the fact that Indonesia has the largest Muslim population in the world, the cuisines in the country, therefore, must follow what Muslim religion believes; that is, they are free of non-halal ingredients, such as pork. These findings pose important implications as to how culinary tourism in Indonesia could be promoted through the appropriate portrayal of food images to international visitors.

\section{Important Expected Factors Prior to Dining with Local Indonesian Food}

To determine the dimensionality of the dining expectation scale, twenty three dining-related items were extracted using Exploratory Factor Analysis (EFA) applying Varimax rotation 
method. The results of the KMO measure of sampling adequacy revealed a value of .799 , which was larger than the minimum cut-off point of .60 . Bartlett's test of sphericity illustrated significance at a level of $.000\left(\chi^{2}=1.783 \mathrm{E} 3, d f=\right.$ 253). As for the dimensionality of the scale assessing visitor dining expectations of local food, $59.24 \%$ of the total variance emerged from the analysis. This provides a better indication that more than half of the variance can be explained by the solution of factor analysis, generating seven distinct factors. All newly extracted factors have Cronbach's alpha coefficients above .50, thus, they meet the minimum cut-off point as required [25]. The seven extracted factors and there corresponding indicators or variables from EFA (Table 1) were found to be:

Factor 1: Staff Quality, contains five items of: communicative staff, knowledgeable staff, responsive staff, friendly staff, and good description of dishes. This factor had the highest eigenvalue (4.977), $21.64 \%$ of the total variance, and a high reliability coefficient of Cronbach's alpha that equalled .72 . The factor was labelled staff quality since it displayed a predominance of items which were associated with the competence of the dining staff. It was reasonable to expect adequate assistance from the staff during the experience of dining on local food, given that they were part of the local community with whom the participants were keen to interact. Additionally, participants were international visitors who might not be familiar with Indonesian food. As such, expecting good service from local staff was understandable as it was considered an important element in enhancing the quality of the dining experience with local food. The importance of this aspect was also confirmed by [26] who stated that besides the food that is being consumed at dining establishment, staff capacity in providing services to customers is also a key determinant in providing memorable dining experiences.

Factor 2: Sensory Appeal, which had an eigenvalue of 2.124, accounting for $9.24 \%$ of the total variance, and a Cronbach's alpha of .74. It was articulated by five items related to: food smells appealing, clean dining place, the use of fresh ingredients, food tastes good, and a pleasant ambience. All are indicative of dining expectations provoked by human senses. In light of this, the factor was named sensory appeal. The emergence of this factor was thought-provoking since the sensory appeal factor was extracted not merely by food-related elements, such as taste, smell, and freshness of the food. It was also determined by sensory appeal concerning the cleanliness and pleasant ambience of the dining establishment where the food consumption took place. This evidence suggests that in dining, the role of items beyond food are considered by international visitors as being just as essential as the food itself and as such, should not be overlooked by relevant tourism authorities. Reference [5] noted that dining experience could offer a pleasurable sensory experience since it involves stimuli from the food that is seen, smelt, tasted, touched, and felt. The results of this study confirm this belief with sensory appeal playing a critical role in motivating participants who were initially unfamiliar with local food to try that food.

Factor 3: Food Uniqueness, showed an eigenvalue of 1.734 , explained $7.54 \%$ of the total variance, and a Cronbach's alpha of .64. Important among the items connected with this factor was: unique way of cooking the food, unique way of eating the food, and unique way of presenting the food. The food uniqueness factor is a reflection of Indonesian's unique way of preparing, serving, presenting, and eating the food. As found in [27] the food uniqueness factor was represented by sensoryrelated aspects, such as being exotic, spicy, and aromatic. However, the findings of this study revealed that the unique aspect of local cuisines composed of elements of food quality outside of the sensory appeal attributes. As described in the preceding paragraph, sensory appeal emerged as a distinct factor with a significant influence on participant expectations.

Factor 4: Local Servicescapes, which was interpreted as the local servicescapes factor comprising three items: dining place is representative of local culture, unique local décor, and dining place provides a welcoming sense of local culture. Unlike the food uniqueness factor which put more emphasis on the food aspect, the three items extracted from the local servicescapes factor were closely associated with the physical aspect of dining, specifically reflecting the local culture. This factor obtained an eigenvalue of 1.348 , described $5.86 \%$ of the total variance, and had a Cronbach's alpha of .70. According to [26], the provision of memorable food experiences during travel cannot be separated from the quality of food service establishments. Reference [29] explained servicescape comprises three dimensions: ambient conditions; spatial layout and functionality; and signs, symbols, and artefacts. In this study, local servicescapes were found to be closely associated with the physical aspect of dining representing local Indonesian culture. These aspects included: the unique design, décor, and layout of the dining establishment; how the place reflected local Indonesian culture, for example, through traditional music played; and how it provided a sense of welcome to visitors. Such findings suggest the important role of this factor as the first 'moment-of- -truth' of the services encountered by the visitors, prior to the actual engagement with the local food itself.

Factor 5: Food Authenticity, which had an eigenvalue of 1.238 , explained $5.38 \%$ of the total variance, and had a Cronbach's alpha of .60. This factor emerged from the correlations of three items: authentic taste, authentically spicy, and exotic food, demonstrating a close link with the authenticity aspect. Food authenticity was the fifth external factor found to significantly contribute to shaping participant dining expectations. It is important to note that this result was in accordance with the preconceptions that the participants had (Figure 1) regarding the major characteristics of Indonesian cuisines that they were required to describe at the beginning of the survey. Most of these initial descriptions were related to the taste of local Indonesian food, which was perceived as spicy, containing lot of herbs and spices, and authentic. 
TABLE 1. SUMMARY OF EXPLORATORY FACTOR ANALYSIS

\begin{tabular}{|c|c|c|c|c|c|c|c|}
\hline Item & $\begin{array}{c}\text { Factor 1 } \\
\text { Staff } \\
\text { Quality }\end{array}$ & $\begin{array}{c}\text { Factor } 2 \\
\text { Sensory } \\
\text { Appeal }\end{array}$ & $\begin{array}{c}\text { Factor } 3 \\
\text { Food } \\
\text { Uniqueness }\end{array}$ & $\begin{array}{c}\text { Factor } 4 \\
\text { Local } \\
\text { Servicescapes }\end{array}$ & $\begin{array}{c}\text { Factor } 5 \\
\text { Food } \\
\text { Authenticity }\end{array}$ & $\begin{array}{c}\text { Factor } 6 \\
\text { Food } \\
\text { Familiarity }\end{array}$ & $\begin{array}{c}\text { Factor } 7 \\
\text { Food } \\
\text { variety }\end{array}$ \\
\hline Knowledgeable staff & .737 & & & & & & \\
\hline Responsive staff to specific needs & .718 & & & & & & \\
\hline Communicative staff & .690 & & & & & & \\
\hline Friendly staff & .565 & & & & & & \\
\hline Good description of dishes & .510 & & & & & & \\
\hline Food smells appealing & & .663 & & & & & \\
\hline Clean dining place & & .615 & & & & & \\
\hline The use of fresh ingredients & & .576 & & & & & \\
\hline Food tastes good & & .545 & & & & & \\
\hline Pleasant ambience/atmosphere & & .527 & & & & & \\
\hline Unique way of cooking the food & & & .751 & & & & \\
\hline Unique way of eating the food & & & .717 & & & & \\
\hline Unique way of presenting the food & & & .704 & & & & \\
\hline Dining place is representative of local culture & & & & .805 & & & \\
\hline Unique local décor & & & & .715 & & & \\
\hline $\begin{array}{l}\text { Dining place provides a welcoming sense of } \\
\text { the culture }\end{array}$ & & & & .578 & & & \\
\hline Authentic taste & & & & & .773 & & \\
\hline Authentically spicy & & & & & .721 & & \\
\hline Exotic food & & & & & .469 & & \\
\hline Flavoured modified for the taste & & & & & & .855 & \\
\hline The use of familiar ingredients & & & & & & .725 & \\
\hline Try local beverage in the dining experience & & & & & & & .768 \\
\hline Wide range of food available on the menu & & & & & & & .763 \\
\hline Eigenvalue & 4.977 & 2.124 & 1.734 & 1.348 & 1.238 & 1.196 & 1.009 \\
\hline Percentage of variance explained & 21.64 & 9.24 & 7.54 & 5.86 & 5.38 & 5.20 & 4.39 \\
\hline Reliability of scale (Cronbach's alpha value) & .72 & .74 & .64 & .70 & .60 & .56 & .51 \\
\hline
\end{tabular}

$\mathrm{KMO}=.799$; Barlett's Test of Sphericity: Approx. Chi-Square $=1.783 \mathrm{E} 3 ; d f=253$, Sig $=.000$; Total variance explained $=59.24 \%$; Extraction method:

Principal Component Analysis; Rotation method: Varimax with Kaiser Normalisation; Rotation converged in 7 iteration

Factor 6: Food Familiarity, which had an eigenvalue of 1.196 , accounting for $5.20 \%$ of the total variance, and showed a Cronbach's alpha of .56. There were two items contributing to the emergence of this factor: flavour modified for taste and the use of familiar ingredients. The appearance of this factor in this study was notable, given that food authenticity, as discussed above also emerged as a significant expected factor. Despite projecting expectations of seeking authenticity in the food, the participants nevertheless expected some familiarity with the local food they intended to eat. Here, this constituted participant familiarity with food ingredients that were known, as well as a degree of flavour modification in the local dishes they wanted to eat. These findings imply that whilst visitors travel in search of novelty and strangeness, most need a degree of familiarity to enjoy their experience. The new factor of food familiarity that emerged from factor analysis in this research was evidence that this factor affects expectations involving dining on local food.

Factor 7: Food Variety, emerged as the seventh or last factor from the analysis. This factor emerged from the correlation of two items: local drink in the destination, and wide range of food available. This factor has an eigenvalue of 1.009 , explains $4.39 \%$ of the total variance, and exhibits a Cronbach's alpha of .51. It is noteworthy to discover that the expectations concerning variety were not exclusively related to local food, but also involved the presence of various options for local beverages.

In addition to those seven underlying factors, as illustrated in Table 2, the MANOVA analysis indicates the influence of frequency of visit on dining expectation levels.

TABLE 2. SUMMARY OF MANOVA ANALYSIS BASED ON PARTICIPANTS' FREQUENCY OF TRAVEL

\begin{tabular}{|l|l|l|l|l|l|}
\hline No & \multirow{2}{*}{$\begin{array}{c}\text { Factors } \\
\text { influencing dining } \\
\text { expectations }\end{array}$} & $\begin{array}{c}\text { First } \\
\text { time } \\
\text { visit }\end{array}$ & $\begin{array}{c}\text { Frequency of Visit } \\
\text { times } \\
\text { visit }\end{array}$ & $\begin{array}{c}\text { More than } \\
\text { 3 times } \\
\text { visit }\end{array}$ & \\
value \\
\hline 1 & Staff quality & 4.19 & 4.16 & 4.28 & .425 \\
\hline 2 & Sensory appeal & 4.38 & 4.44 & 4.45 & .405 \\
\hline 3 & Food uniqueness & 3.37 & 3.57 & 3.59 & .084 \\
\hline 4 & Local servicescape & 3.58 & 3.50 & 3.58 & .784 \\
\hline 5 & Food authenticity & $3.60^{\mathrm{a}}$ & 3.65 & $3.89^{\mathrm{a}}$ & $.021^{*}$ \\
\hline 6 & Food familiarity & $3.13^{\mathrm{a}}$ & $2.70^{\mathrm{a}}$ & 2.88 & $.003^{*}$ \\
\hline 7 & Food variety & 3.87 & 3.76 & 3.76 & .490 \\
\hline \multicolumn{2}{|l|}{ Participants $(\mathrm{n})$} & 213 & 59 & 60 & \\
\hline \multicolumn{2}{|l|}{ Wilks' Lambda $=.894 ; F$ value $=2.567 ; p$ value $=.001$} & \\
\hline
\end{tabular}

* denotes statistically significant difference $(p$ value $\leq .05){ }^{\text {ab }}$ identify the presence of significant $\beta$ differences between the groups based on posthoc tests with the Tukey's HSD.

The Wilk's Lambda of .894, the $F$ value of 2.567, and the $p$ value of .001 showed a statistically significant difference amongst respondents who travelled to Indonesia for the first 
time, 2-3 times, and more than 3 times in terms of their overall dining expectations. In other words, a significant effect of the frequency of visit attribute was found on the visitor's dining expectation. Specifically, out of seven dining expectation factors, two dependent variables, which were food authenticity and food familiarity, recorded a significant value less than the cut-off of .05. In regard to food familiarity, as illustrated in Figure 2, participants who were visiting Indonesia for the first time expressed higher expectations (mean $=3.13$ ) than those who had previously travelled to the country for 2-3 times (mean=2.70). In the context of this study, food familiarity pertains to the ingredients used and to the flavour of the food. It is unsurprising, therefore, to find that those who travelled to Indonesia for the first time, expected to encounter food that was more familiar to them, compared with those who had visited Indonesia before (assuming that they had previous dining experience with local Indonesian food). By contrast, in terms of food authenticity, those who had ever travelled to the country before projected significantly higher expectations concerning this factor than those who were first time visiting Indonesia. This finding is reasonable, given the assumption that those who had travelled to Indonesia might had the experience of dining with local Indonesian food in their previous visit, which in turn, would build their conception about how authentic traditional Indonesian culinary should be delivered.

\section{CONCLUSION AND SUGGESTION}

As an exploratory study, this research has offered a practical contribution to Indonesia's tourism industry to the improved understanding of international visitor dining behaviour. It is anticipated that the revealed findings would help the relevant stakeholders design their culinary tourism strategies on a market-driven basis. The results showed seven underlying factors that affect participant dining expectations with local Indonesian food, namely: staff quality; sensory appeal; food uniqueness; local servicescapes; food familiarity; food authenticity; and food variety factors. In terms of frequency of travel, the finding shows significant differences between first time and repeater travellers in expecting food authenticity and food familiarity factors. It is important to note that the service quality of local staff and food-cultural related factors are amongst the most critical factors should be paid into attention when catering to the international market.

Despite significant contribution offered by this study, several limitations of this study should be acknowledged. First, due to resource constraints, the empirical investigation was only conducted in the geographical scope of Surabaya and Malang cities in East Java province, which might have resulted in possible cultural setting bias. That is, this study does not represent the whole region of Indonesia whose food culture is very diverse. Accordingly, this research should not be widely interpreted to be representative of the general experiential examination on dining with all local
Indonesian food. It is therefore recommended that future studies should be conducted in other destination contexts and/or in other cultural settings. Second, a total of 349 participants was still considered too small to enable the researchers to conduct a group comparison according to various socio-demographics and travel characteristics. Thus, to enhance generalisability of the study findings, it is recommended to incorporate a greater sample size that would contribute to higher reliability and validity of the data.

\section{REFERENCES}

[1] R. C. Y. Chang, J. Kivela, and A. H. N. Mak, "Attributes that influence the evaluation of travel dining experience: When East meets West," Tourism Management, vol. 32, pp. 307-316, 2011.

[2] E. Cohen and N. Avieli, "Food in tourism: Attraction and impediment," Annals of Tourism Research, vol. 31, pp. 755-778, 2004.

[3] J. Hegarty, A. and B. O'Mahony, G., "Gastronomy: A phenomenon of cultural expressionism and an aesthetic for living," Hospitality Management, vol. 20, pp. 3-13, 2001.

[4] L. M. Long, Culinary tourism. Kentucky: The University Press of Kentucky, 2004.

[5] J. Kivela and J. C. Crotts, "Tourism and gastronomy: Gastronomy's influence on how touritsts experience a destination," Journal of Hospitality \& Tourism Research, vol. 30, pp. 354-377, 2006.

[6] E. Ignatov and S. Smith, "Segmenting Canadian culinary tourists," Current Issues in Tourism, vol. 9, pp. 235-255, 2006.

[7] D. Yun, S. Hennessey, and R. MacDonald, "Understanding culinary tourists: Segmentation based on past culinary experiences and attitudes toward foodrelated behaviour," presented at the International CHRIE Conference, Amherst, 2011.

[8] J. Kivela and J. C. Crotts, "Gastronomy tourism: A meaningful travel market segment," Journal of Culinary Science \& Technology, vol. 4, pp. 39-55, 2005.

[9] B. McKercher, F. Okumus, and B. Okumus, "Food tourism as a viable market segment: It's all how you cook the numbers!," Journal of Travel \& Tourism Marketing, vol. 25, pp. 137-148, 2008.

[10] B. Okumus, F. Okumus, and B. McKercher, "Incorporating local and international cuisines in the marketing of tourism destinations: The cases of Hong Kong and Turkey," Tourism Management, vol. 28, pp. 253-261, 2007.

[11] Chaney, S., \& Ryan, C. (2012). Analyzing the evolution of Singapore's World Gourmet Summit: An example of gastronomic tourism. International Journal of Hospitality Management, 31(2), 309-318.

[12] J. C. Henderson, O. S. Yun, P. Poon, and X. Biwei, "Hawker centres as tourist attractions: The case of 
Singapore," International Journal of Hospitality Management, vol. 31, pp. 849-855, 2012.

[13] H.-T. Chuang, "The rise of culinary tourism and its transformation of food cultures: The national cuisine of Taiwan," The Copenhagen Journal of Asian Studies, vol. 27, pp. 84-108, 2009.

[14] Y.-C. Lin, T. E. Pearson, and L. A. Cai, "Food as a form of Destination Identity: A Tourism Destination Brand Perspective," Tourism and Hospitality Research, vol. 11, pp. 30-48, January 1, 20112011.

[15] J.-S. Horng and C.-T. Tsai, "Culinary tourism strategic development: an Asia-Pacific perspective," International Journal of Tourism Research, vol. 14, pp. 40-55, 2012.

[16] Ministry of Tourism and Creative Economy of the Republic of Indonesia, "Statistical report on visitor arrival to Indonesia 2014," Jakarta: Ministry of Tourism and Creative Economy of the Republic of Indonesia, 2014.

[17] OECD, "OECD tourism trends and policies 2012," ed. Paris: The Organisation for Economic Co-operation and Development (OECD), 2012.

[18] Yurnaldi, "Pariwisata Indonesia jauh ketinggalan [Indonesian tourism is left behind]," in Kompas, ed. Jakarta: Kompas Gramedia Group, 2010.

[19] Y. Alamsyah, Bangkitnya bisnis kuliner tradisional [The rise of traditional culinary business]. Jakarta: PT. Elex Media Komputindo, 2008.

[20] N. L. M. Pertiwi, "Kuliner Indonesia layak dipromosikan [Indonesian culinary is well-deserved to be promoted]," in Kompas, ed. Jakarta: Kompas Gramedia Group, 2011.

[21] F. Prawitasari, "Inilah 30 ikon kuliner tradisional Indonesia $[30$ icons of traditional Indonesian culinary]," in Kompas, ed. Jakarta: Kompas Gramedia Group, 2012.

[22] Garuda Indonesia. (2012, 8 October). Garuda Indonesia experience. Available: http://www.garudaindonesia.com/gi_us/Garuda+Indonesia+Experience/G aruda+Indonesia+Experience.page?

[23] H. S. Widianto, "Bandung is Appointed as Culinary Tourism Destination," in Pikiran Rakyat, ed. Jakarta: Pikiran Rakyat, 2015

[24] J. C. Henderson, "Food tourism reviewed," British Food Journal, vol. 111, pp. 317-326, 2009.

[25] J. Pallant, SPSS survival manual: A step by step guide to data analysis using SPSS, 4th ed. Crows Nest, NSW: Allen \& Unwin, 2011.

[26] D. Gibbs and C. Ritchie, "Theatre in restaurants: Constructing the experience," in The tourism and leisure experience: Consumer and managerial perspectives, M. Morgan, P. Lugosi, and B. J. R. Ritchie, Eds., ed Bristol: Channel View Publications, 2010, pp. 182-201.

[27] S. Jang, A. Ha, and C. A. Silkes, "Perceived attributes of Asian foods: From the perspective of the American customers," International Journal of Hospitality Management, vol. 28, pp. 63-70, 2009.

[28] S. Smith, C. Costello, and R. A. Muenchen, "Influence of push and pull motivations on satisfaction and behavioral intentions within a culinary tourism event," Journal of Quality Assurance in Hospitality \& Tourism, vol. 11, pp. 17-35, 2010.

[29] M. J. Bitner, "Servicescapes: the impact of physical surroundings on customers and employees," The Journal of Marketing, vol. 56, pp. 57-71, 1992. 